\title{
Entrevista ao arquiteto Rui Mendes
}

\section{Filipa Ramalhete}

framalhete@autonoma.pt

Centro de Estudos de Arquitetura, Cidade e Território da Universidade Autónoma de Lisboa (CEACT/UAL), Portugal | Centro Interdisciplinar de Ciências Sociais da Universidade Nova de Lisboa (CICS.Nova)

\section{João Caria Lopes}

joaocarialopes@gmail.com

Atelier BASE | Centro de Estudos de Arquitetura, Cidade e Território da Universidade Autónoma de Lisboa (CEACT/UAL), Portugal

Para citação: RAMALHETE, Filipa; LOPES, João Caria - Entrevista ao arquiteto Rui Mendes. Estudo Prévio 14. Lisboa: CEACT/UAL - Centro de Estudos de Arquitetura, Cidade e Território da Universidade Autónoma de Lisboa, 2018. ISSN: 2182-4339 [Disponível em: www.estudoprevio.net]. DOI: https://doi.org/10.26619/2182-4339/14.3

Creative Commons, licença CC BY-4.0: https://creativecommons.org/licenses/by/4.0/ 


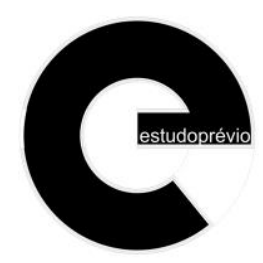

PT | E01 | EP14 | w2018

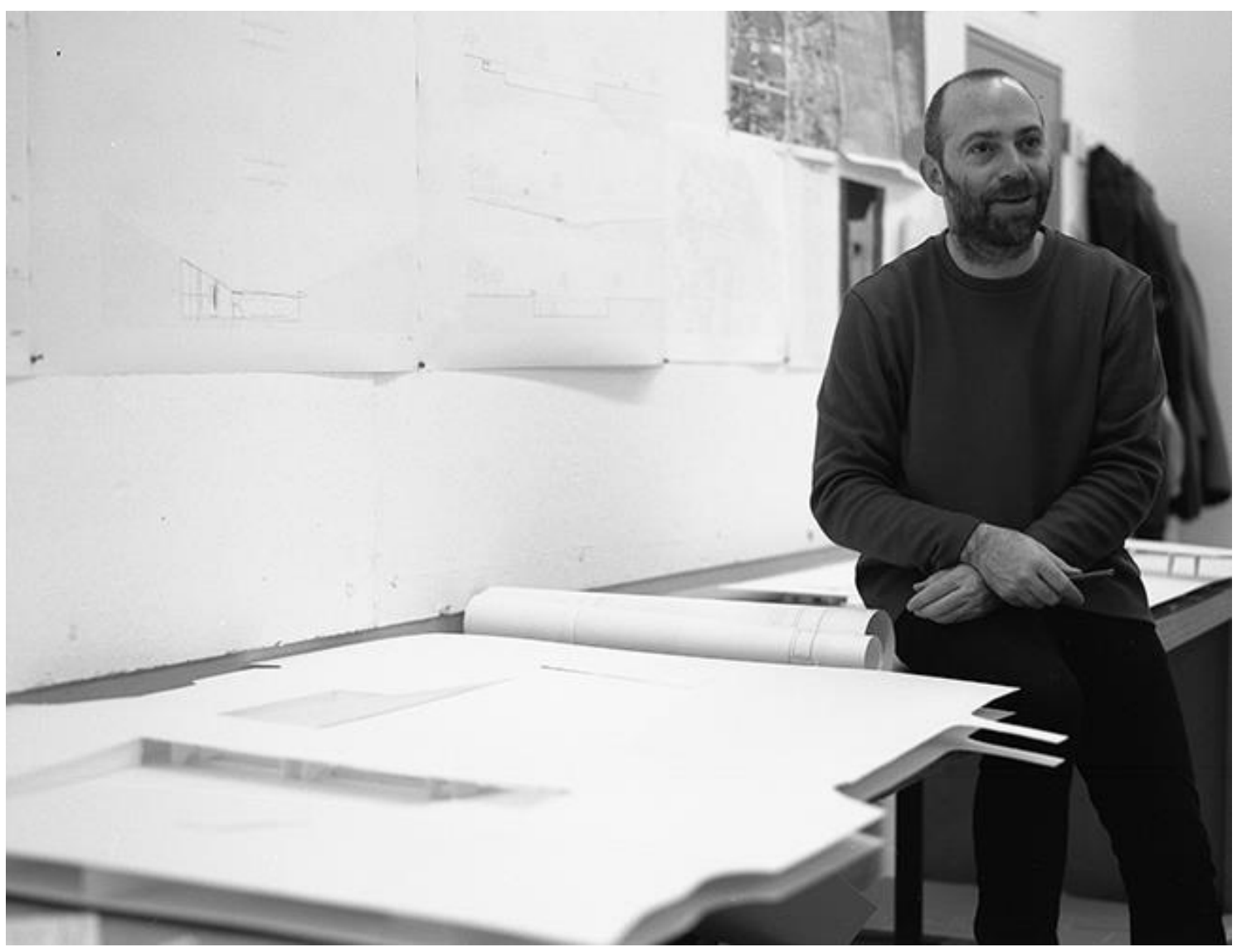

É com enorme prazer que hoje temos como nosso convidado o arquiteto e professor Rui Mendes. Seja bem-vindo. Queríamos começar por pedir que nos contasses um pouco do teu percurso académico como aluno, como foi o curso de arquitetura, professores ou exercícios marcantes.

Obrigado pelo convite. É com enorme prazer que estou aqui. O percurso académico foi feito na Universidade Lusíada em Lisboa, no início dos anos 90, e foi um curso, assim visto em retrospetiva, bastante confuso. Havia muito pouca reflexão sobre arquitetura, senti, de uma forma muito imediata, que havia um grau de autodidatismo que era preciso introduzir no curso. Passei o primeiro ano de uma forma bastante episódica, porque não senti grande apelo pelas aulas. Além dos professores do primeiro ano, o Nuno Simões e a Bárbara São Miguel, que são sempre importantes, não houve outros professores de projeto que eu possa referir como muito importantes, a não ser no quinto ano, quando conheci o arquiteto Manuel Tainha; e aí acho que encontrei um professor. Era aluno do arquiteto Orlando Azevedo (com o arquiteto Joaquim Braizinha), mas acho que encontrei no arquiteto Tainha o professor que me marcou - que depois vim a contactar já como arquiteto formado, porque o meu primeiro atelier foi no edifício onde o arquiteto Tainha tinha o seu atelier e acabámos por ser vizinhos. 
Durante o curso, os professores que acabaram por me marcar mais foram os de Desenho e os de História, já no terceiro ou quarto ano, se não me engano... Foi quando tive como professor o João Rodeia, que foi bastante importante porque ele era muito entusiasta, organizava viagens com os alunos - fomos a Paris com ele, e foi impecável! Talvez tenha sido a primeira viagem de escola que eu fiz... e ajuda imenso! A relação com os colegas passa a ser outra, há outras relações com a arquitetura que se promovem, e isso foi muito importante. Os professores de Desenho eram o Sérgio Rebelo, o Miguel Navas e a Teresa Rodeia.

$\mathrm{Na}$ altura do quarto ano, comecei a querer trabalhar em simultâneo. Comecei a trabalhar com o arquiteto Mateus Lorena, de uma forma pouco formal, digamos assim, com algum tempo que tinha disponível da escola. E, de facto, os grandes amigos do arquiteto Mateus eram este grupo de professores de Desenho e acabávamos por estar juntos fora da escola também, hoje em dia somos amigos. Talvez esse tenha sido o resíduo mais interessante que resultou da escola, essa comunhão com pessoas que tinham sido meus professores, que hoje são amigos.

Houve um arquiteto cujo trabalho me interessou também perceber, que foi o professor

Reais Pinto. Era professor de construções, muito dedicado às pré-fabricações e coisas assim pesadas, obras muito pouco referenciadas na altura, mas que, mais tarde, me têm dado algum gozo conhecer. Isso talvez tenha sido um preâmbulo relevante para o meu trabalho, que é juntar uma série de coisas dentro do atelier, do projeto, investigações periódicas e obsessões permanentes...

\section{Para ti, a continuidade entre universidade $e$ atelier ou mercado de trabalho, foi uma coisa fluida?}

Não, não foi. Eu acabei o curso em 1996/7 e, até 2003/4, não tive nenhum contacto com a escola. Nessa altura estava muito indeciso sobre o que é que havia de fazer. $E$ nessa altura as viagens foram muito importantes. Quer as da escola, quer as que organizávamos fora - coincidiu com um período em que fiz muitas viagens, estadias longas, patrocinadas pelo Rotary Club, que era um clube a que o meu pai pertencia que tinha sócios no mundo inteiro, organizavam workshops/campos de estudo. E eu acabei por ter uma estadia longa em Itália, no Lago de Como, outra na Dinamarca, na floresta negra na Alemanha, na Grécia, etc...

De repente, começamos a ter trabalho no atelier, já em associação com o Mateus Lorena, mas às tantas, aquele pragmatismo - o trabalho com o Mateus foi sempre muito estimulante - sobretudo aquela relação com os clientes e com o mercado de trabalho, era algo para que eu não estava ainda preparado.

Já tinha duas cartas preparadas para enviar - uma para o Siza e outra para o Josep Quetglas, que era um arquiteto que eu tinha começado a ler na escola e me interessava - mas um dia decidi responder a um concurso para Beja. E fui trabalhar para Beja, saí de lisboa. Não fui para o Porto trabalhar com o Siza. Não fui para Barcelona contactar o Quetglas. Fui para Beja. Um sítio onde nunca tinha ido, e não fazia a mínima ideia do que ia fazer. Sei que o concurso me estimulava, era fora de 


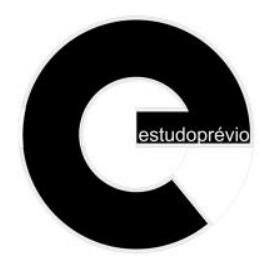

PT | E01 | EP14 | w2018

Lisboa, e que dizia no preâmbulo do concurso o que eu queria: fazer projetos para aquele território!

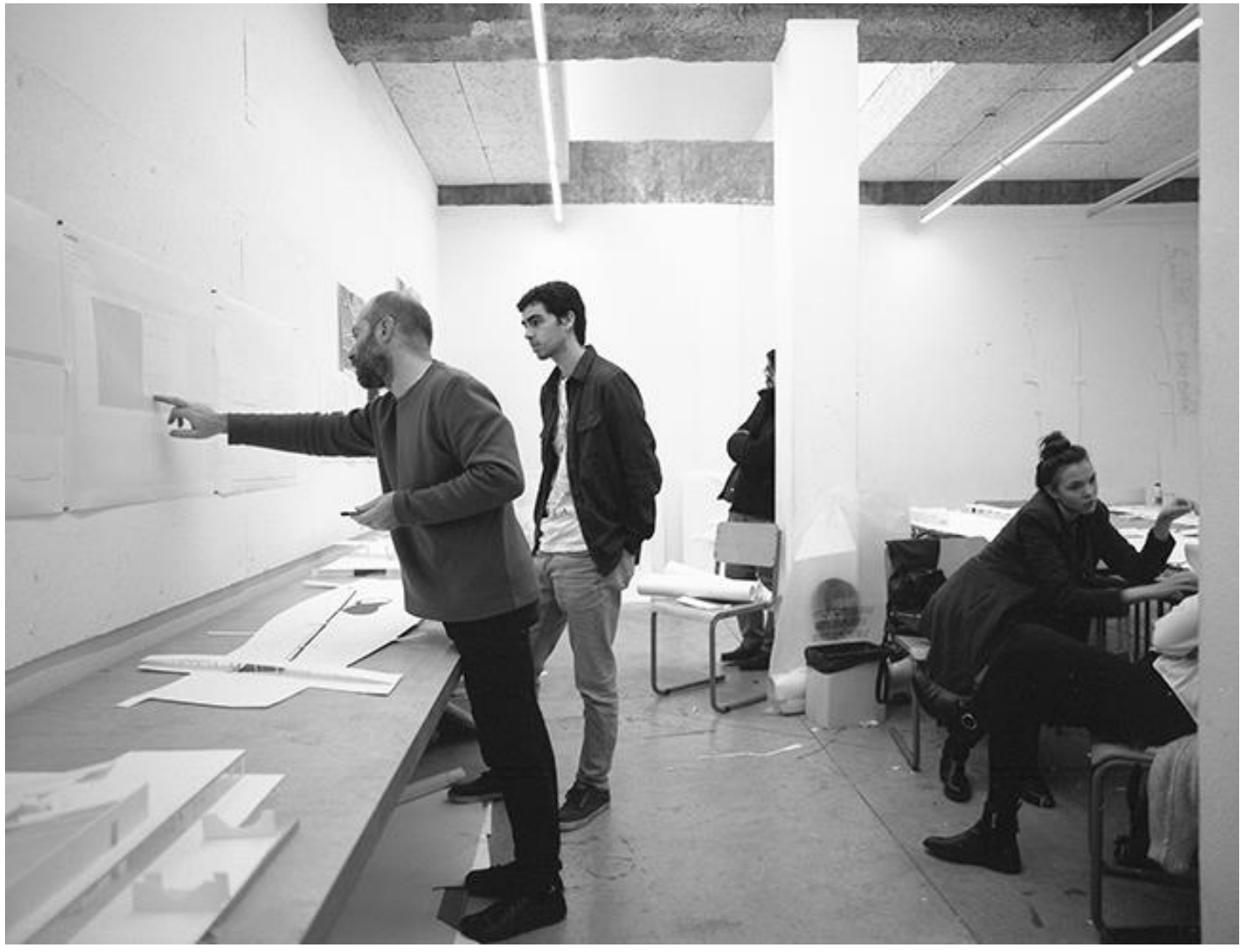

\section{Era na Câmara Municipal?}

Foi na Câmara Municipal. Foi um ano, porque o contrato era assim, e nesse ano estive completamente à solta! Havia uma pessoa lá na Câmara, que era eu, que fazia projetos. Mas quais projetos? Então era preciso também inventá-los, não é? Era mesmo preciso! E houve duas coisas muito estimulantes que fiz, no início. Tinha um motorista por minha conta e tinha de fazer apenas uma coisa, que era conhecer aquele território. O senhor presidente tinha dito: "olhe você agora antes de lhe darmos projetos incríveis para fazer, tem que conhecer isto e, portanto, tem aqui um senhor impecável à sua disposição que vai fazer um roteiro e assim vai conhecer isto e tal..." E pronto, assim foi...

Todos os dias, às sete da manhã, lá estávamos preparados para seguir viagem e, até às duas da tarde, fazíamos um percurso por todas as aldeias, por todas as ruas, a falar com as pessoas. Isto tinha um desígnio, que eu não sabia à partida, que era um grande concurso, uma coisa muito acarinhada na Câmara, que se chamava 0 "Concurso da Rua Caiada" e que era o concurso que elegia todos os anos a melhor rua daquele sítio. 


\section{A Câmara fornecia os materiais, não era? A Câmara fornecia a cal e os pinceis.}

Oferecia a cal, os pinceis, e as pessoas caiavam como uma festa, e era uma festa muito partilhada entre as mulheres e os homens, cada um tinha a sua função naquele registo, e isso foi uma coisa muito curiosa e muito bonita, que eu gostei de conhecer, uma versão da Arquitetura Popular que eu ainda só conhecia do Inquérito à Arquitetura Popular em Portugal (1961); não conhecia aquela escala, não conhecia aqueles materiais. E foi incrível! Foram três meses de uma espécie de ensaio sobre erudição popular, que era qualquer coisa de que, na escola, ninguém falava... $E$ aquela experiência construiu um lastro de vontade de, pelo menos, permanecer mais algum tempo e tentar construir alguma coisa com aquele conhecimento; e isso alimentou conhecer melhor o Inquérito, conhecer melhor aquelas realidades rurais. $\mathrm{Na}$ altura, isto foi nos finais dos anos 90, 1998/99, em Beja, coincidiram uma série de pessoas, entre arquitetos, fotógrafos e alguns artistas que também estavam quase na mesma condição que eu: estavam fora do seu sítio. Também teve sempre esse lado de descoberta, ninguém era de lá, havia muitos arquitetos que conheci lá e que estavam também seduzidos por essa cultura erudita...

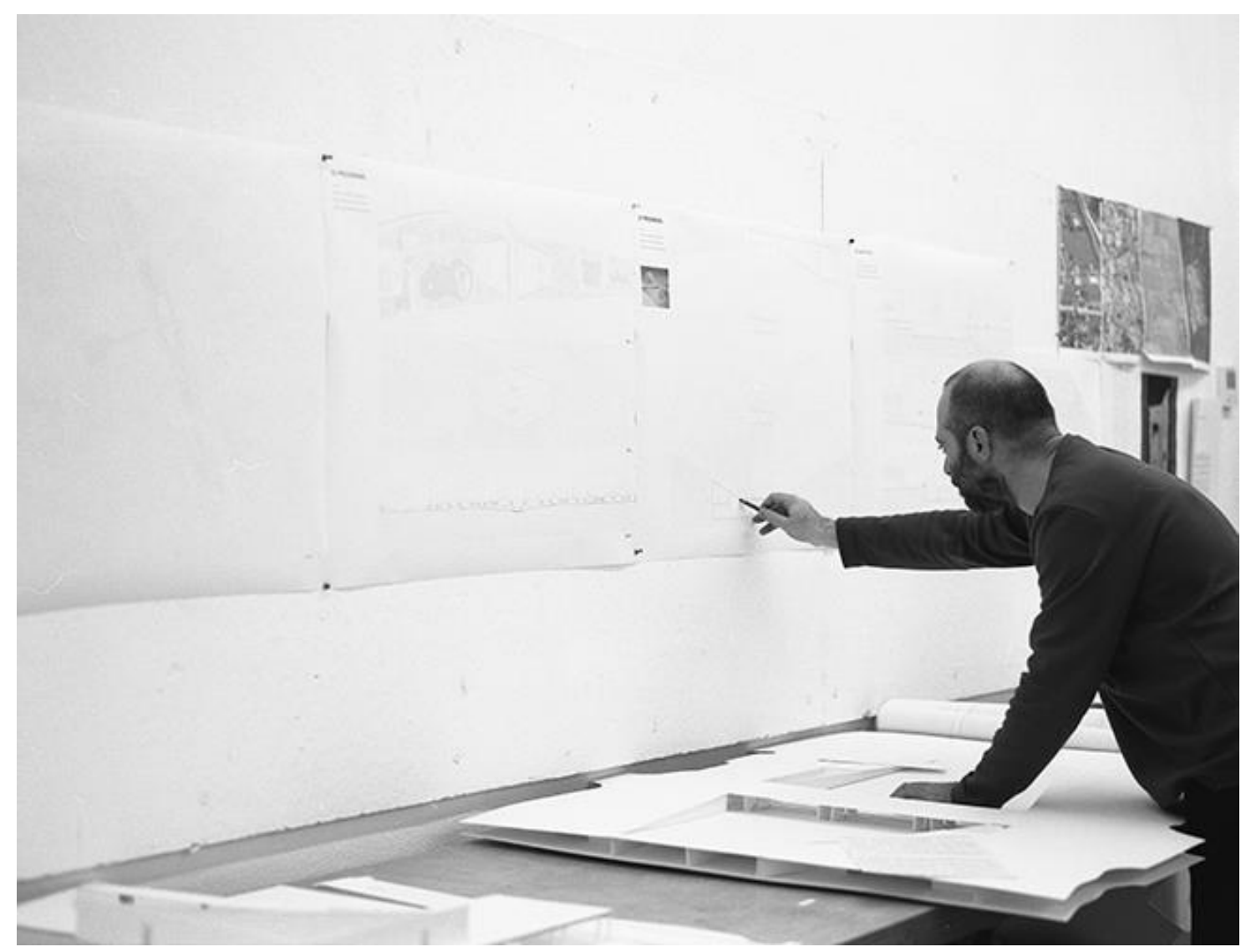




\section{Estava a Barragem do Alqueva em construção, não é? Nessa altura devia estar quase a encher?}

Já tinha começado. E também já havia algum distanciamento daquela pobreza que dominou muito aqueles territórios e, portanto, já havia capacidade de planear alguns acontecimentos. E aí é que surgiram os projetos que a Câmara me foi pedindo para fazer - a Casa Mortuária de Santa Vitória; o Salão de Festas de Trigaches; uma pequena ampliação do Estádio de Beja, uma casa para uma família cigana. Tudo isso foi começado e nada foi construído! Porque chegava a uma altura em que, digamos, havia um domínio político das decisões, e era bastante difícil passar para a obra sem que houvesse um escrutínio absoluto das juntas de freguesia, daquelas estruturas menos avisadas para outros universos que não aqueles de caráter popular, que diziam conhecer. A única coisa que eu consegui construir nesse ano foi uma coisa completamente singular e quase invisível, que era um caixote do lixo de pequena dimensão para o centro da cidade, que depois foi produzido em escala, eram cerca de 1500 , se bem me lembro. No final da história decidi que me vinha embora porque nada se concretizava, mas, no fundo, a primeira grande relação com a arquitetura, esta experiência ao vivo do Inquérito à Arquitetura, é aquilo que eu retenho. E uma série de amigos que ficaram para a vida. Esta é a primeira etapa que, se calhar, acaba a fase de aprendizagem. Que nunca é simples nem estanque.

\section{Pode dizer-se que abriste o caminho?}

Não. Eu não abri o caminho, quem abriu o caminho talvez tenha sido o arquiteto Manuel Faião que ainda lá está. E o arquiteto Eugénio Castro Caldas que fica como consultor da Câmara, depois do arquiteto Hestnes Ferreira ter feito esse primeiro caminho. $\mathrm{O}$ arquiteto Castro Caldas sai do atelier do Hestnes Ferreira e fica com o acompanhamento de Beja, de Serpa e de Mértola. Mas, antes disso, ainda houve outros grandes arquitetos que fizeram trabalhos importantes em Beja, sobretudo o José Rafael Botelho, que foi o primeiro consultor de arquitetura da Câmara, nos anos 50 , e que, durante algum tempo, produziu trabalho de levantamento importante que deu origem ao Plano de Salvaguarda da cidade. E depois o arquiteto Cristino da Silva projeta o grande Liceu de Beja, o arquiteto Raul Chorão Ramalho, constrói o Hospital, o arquiteto Francisco Keil do Amaral, constrói o Hotel da Base Aérea no Bairro dos Alemães, e toda a obra do arquiteto Hestnes Ferreira dos anos 70/80. Mais recentemente, o arquiteto Pedro Viana Botelho com a ampliação do Liceu de Beja. Como veem o caminho já é longo. Sem falarmos na Beja Romana (que continua em escavação), há uma serie de ótimos arquitetos que, em tempos diferentes, vão trabalhar a Beja. 


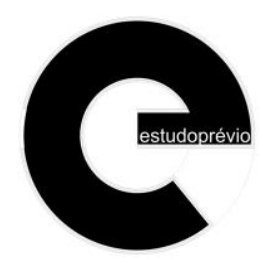

PT | E01 | EP14 | w2018

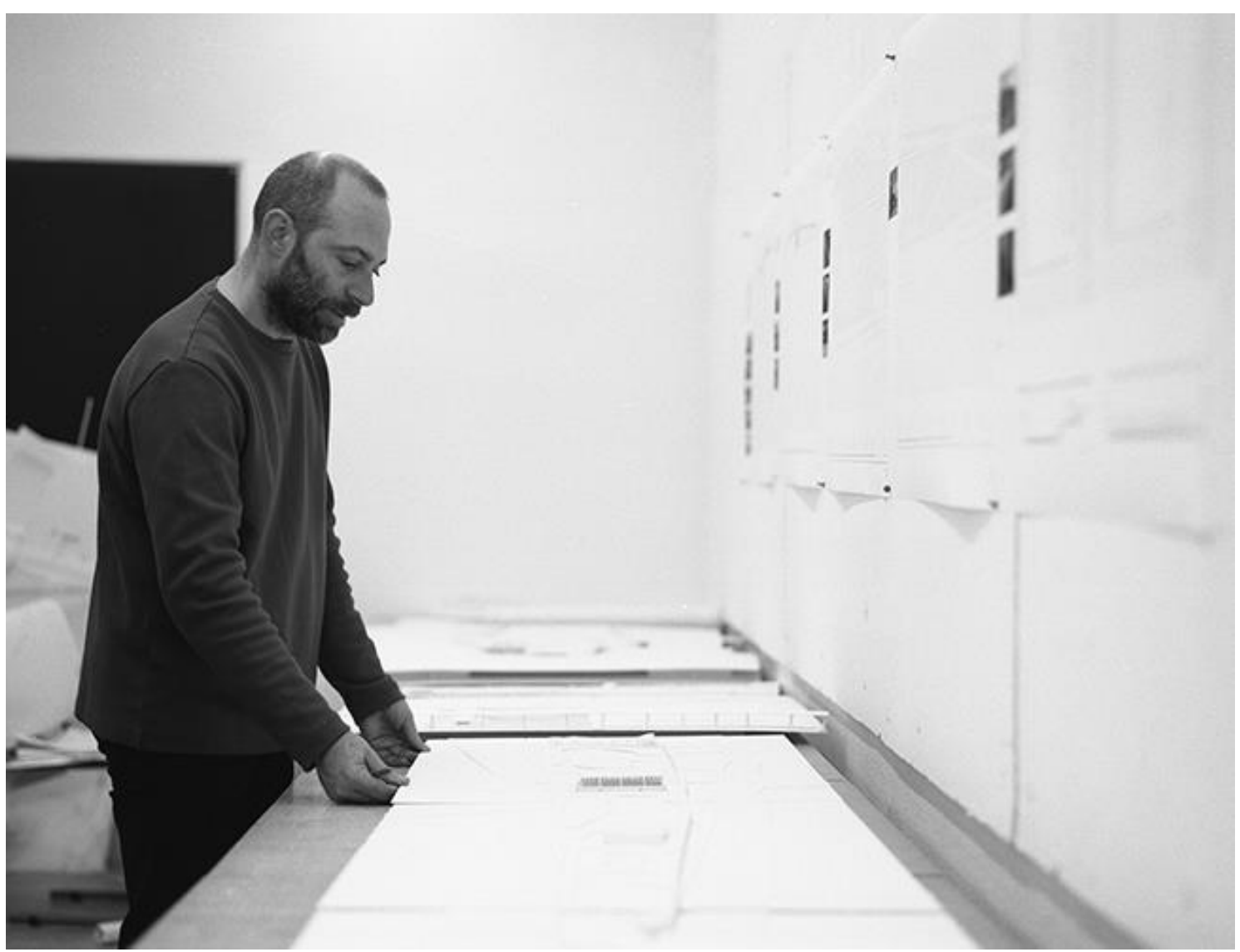

Isso quer dizer que também foi um contacto com uma série de pessoas que, não sendo os nomes que tu estavas à procura, tinham uma prática $e$ um saber-fazer que não terias encontrado noutro sítio, não é?

Sim, eu acho que foi inusitado, foi não-preparado, mas claro que sim. Eu, na altura, saí da escola e sabia muito pouco para além das referências mais universais. Quer da arquitetura internacional, quer da nacional. Havia muito pouca produção, até impressa e publicada. E encontro arquitetos de que nunca tinha ouvido falar, que nunca tinham estado em nenhuma conversa, em nenhum debate. Quer na escola, quer nos ateliers.

Agora fizeste-me lembrar que houve uma conferência, nessa altura, do arquiteto Pedro Pacheco, ali em Beja, a propósito do seu Museu da Luz. Eu conheci o Pedro Pacheco nessa conferência e, depois, chego a Lisboa e vou trabalhar para o atelier dele e do José Adrião. Acabo o primeiro ano de Beja, venho para Lisboa, e vou lá bater à porta. Apetecia-me ir trabalhar para um atelier relativamente pequeno, e o atelier do José Adrião e do Pedro Pacheco era um atelier de quem as pessoas falavam na altura, em Lisboa. E foi no Atelier JAPP que vim a conhecer o Fernando Martins com quem fiz projetos em associação. 


\section{E queres contar-nos a história de como foi até teres o teu atelier?}

Foi rápido, de facto, estive um ano e meio a trabalhar com o José Adrião e o Pedro Pacheco, no atelier deles, ainda juntos. Assisti nesse momento à separação em dois ateliers. Trabalhei com eles num trabalho para Matosinhos e depois só com o Pedro Pacheco na Aldeia da Estrela, no Cemitério da Estrela. Nessa mesma altura, tive a encomenda da Casa de Santa Vitória, em Beja, ainda comecei o trabalho dentro do atelier, mas houve um dia em que decidi sair - que é uma coisa que talvez hoje seja impensável, porque tinha apenas um trabalho - decidi "olha, tenho um trabalho, está mesmo bom para ir para um sítio meu!".

\section{Isso foi em que ano?}

Isto foi em 2000/01. Vim para Lisboa em 1999, trabalhei no atelier JAPP e em 2001 é que acontece esse começo de atelier. $\mathrm{E}$ foi um começo com um projeto!

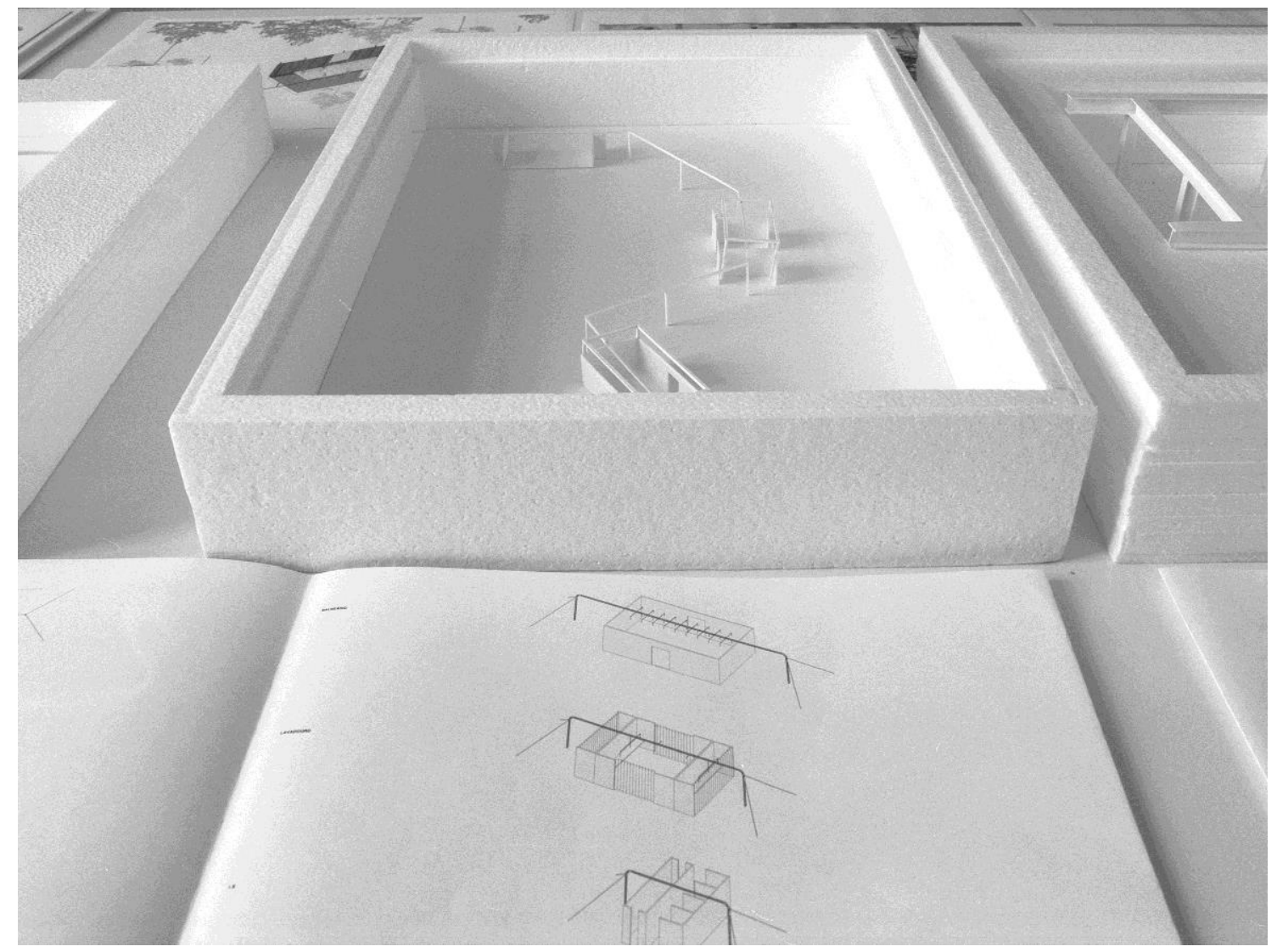

\section{E um arquiteto. Estavas sozinho nessa altura?}

Sim, estava sozinho. Há um preâmbulo deste acontecimento. Na altura, já não trabalhava com $o$ arquiteto Mateus Lorena mas algumas coisas tinham ficado por fazer, alguns trabalhos... E, nessa altura, fomos convidados para fazer um concurso para uma escola no Braço de Prata e juntámos uma equipa grande, com o José Maria 
Assis, o Tiago Oliveira, com a Patrícia Barbas, com o João Nunes, com o Pere Buil e o Jordi Fornells - uma série de gente que trabalhava no Atelier do Bugio, do arquiteto João Favila, com o Gonçalo Byrne ou com o Manuel Aires Mateus - e, de repente, montámos uma equipa. $E$ depois desse concurso feito e entregue, não ganhámos. Foi o arquiteto Telmo Cruz que ganhou esse concurso, mas também não foi construído, infelizmente. Depois desse acontecimento, fundei o atelier.

Montámos um atelier, em conjunto, no mesmo sítio, ocupando um espaço grande no Príncipe Real, com o Jordi Fornells e o Pere Buil. Estava sozinho a fazer esse único trabalho, mas o atelier era um conjunto de micro-ateliers, que se manteve durante dez anos. Era um atelier bastante curioso, porque era onde estava a Luciana Fina, que é videasta, estava a Vera Mantero, com o Rumo do Fumo, estava o Teatro do Vestido, o Miguel Gonçalves Mendes, o realizador. Foi um sítio por onde passou imensa gente e tínhamos todos vontade de partilhar o que íamos fazendo e, até hoje, é uma versão que partilho com o atelier do arquiteto Jordi Fornells, aqui em Lisboa.

\section{E sempre quiseste ser arquiteto?}

Sim. Apesar de não ter grande narrativa para contar sobre isso, sei que quando quis fazer um curso superior, só havia duas hipóteses: ou era arquitetura ou cinema, mas cinema acabou por não contar nesse momento, e concorri a Arquitetura. Na verdade, dizem os meus pais que não existiram dúvidas.

\section{E durante o curso foste sedimentando essa vontade, essa escolha?}

Sim, sim, foi só durante o curso.... Acho que só a meio do curso é que o interesse aconteceu com algum vigor.

\section{O Manuel Tainha foi professor de muitos dos nossos entrevistados, mas numa fase anterior. Tu eventualmente apanhaste-o já numa fase mais madura. Queres falar um pouco sobre essa experiência?}

A verdade é que eu não fui aluno dele. Eu ia às aulas do arquiteto Manuel Tainha não sendo seu aluno formal. Eu era aluno de quinto ano do arquiteto Braizinha e tinha aulas com o Orlando Azevedo, que me lembro ser um arquiteto bastante preocupado com questões pedagógicas. Tínhamos boas conversas sobre os processos de trabalho. Acho que talvez aquilo me estimulava para também ir às aulas do Tainha. Penso que foi o seu último ano de professor, portanto foi mesmo o fim da sua atividade como professor e talvez tenha sido por isso que eu tenha ficado com essa memória de que as aulas eram muito sérias, num determinado sentido. As frases eram muito bem ditas e aquilo que ele tinha para dizer era uma coisa que eu sentia que estava muito fundado na sua obra, soava-me como solidez, como qualquer coisa de que eu de certeza me iria lembrar, e, portanto, ia às suas aulas, a partir desta convicção. Ele não me deu nenhuma nota, não me avaliou em nada, mas talvez tenha sido o professor que ouvi mais tempo e mais vezes. 


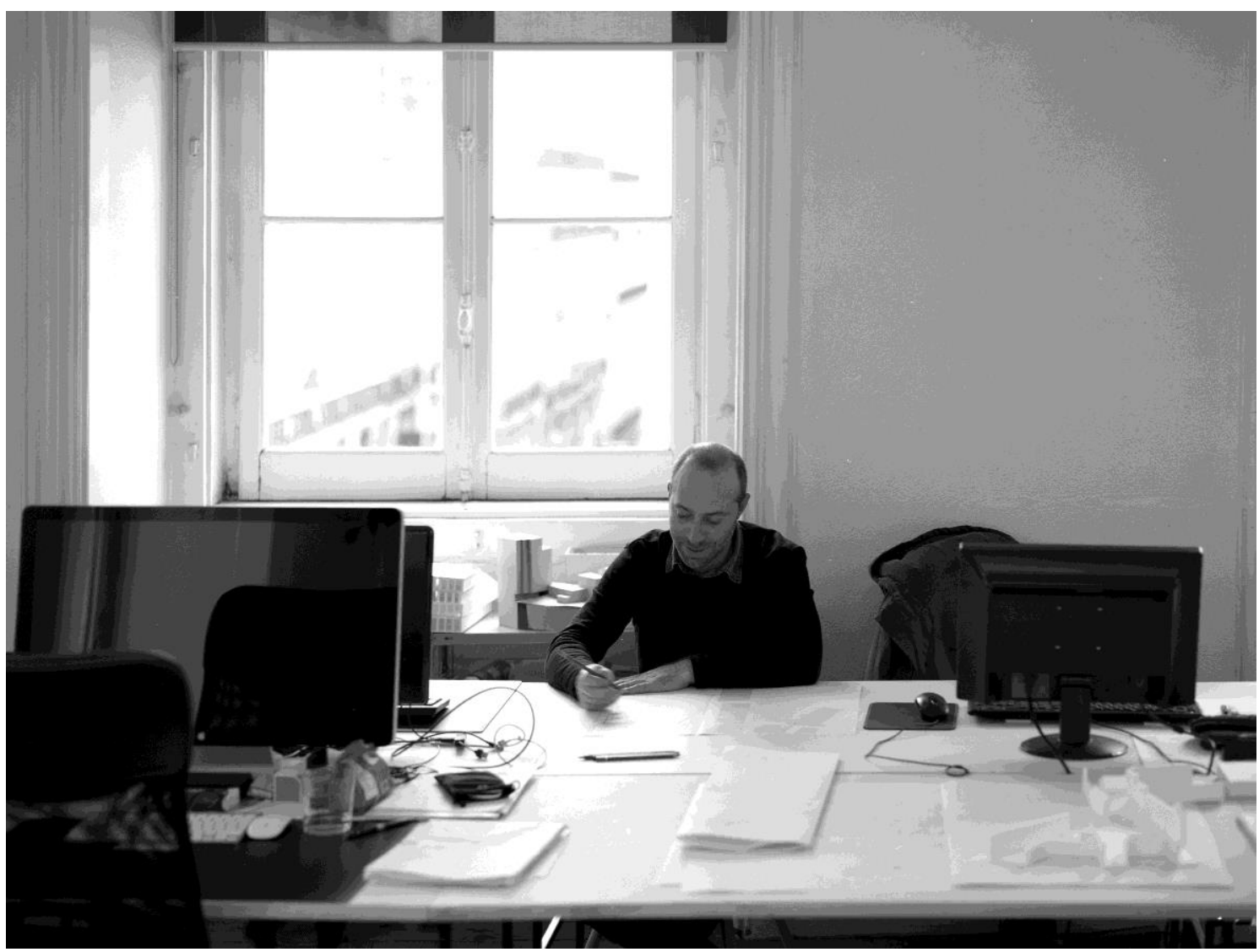

\section{Hoje em dia lecionas na Universidade Autónoma de Lisboa. Sempre tiveste essa vontade de ser professor de Arquitetura?}

Sim, a determinada altura. O primeiro convite que eu tive para ser professor foi do arquiteto Ricardo Carvalho, ainda enquanto ele estava na Universidade Moderna, com uma série de pessoas que hoje também estão na Autónoma, ou noutras universidades. Lembro-me de que, naquela altura, em 2004/2005 - eu e o Ricardo Carvalho, conhecemo-nos a fazer o Inquérito da Arquitetura do Século XX, que a Ordem organizou, com a Ana Tostões a coordenar - o Ricardo já era professor, já tinha feito esse caminho e, na altura, convidou-me para a Moderna para dar aulas de Teoria.

Tu estava com o Inquérito e com outra coisa que estava a fazer para a Ordem - uma investigação sobre o arquiteto Pires Branco, na altura da Presidente Helena Roseta; no fundo, era um estudo sobre um conjunto de arquitetos dentro dos modernos não canónicos, que tinham ficado na província - e, como queria fazer tudo bem, achei que podia esperar para ter essa experiência como professor e disse ao Ricardo que ainda não era agora. Em simultâneo, o Ricardo Carvalho é convidado para ir para a Autónoma, e logo a seguir, começou a acontecer eu ir à Autónoma fazer críticas, fazer um seminário, fazer um workshop e, portanto, essa vontade foi ainda mais estimulada por esses convites pontuais para fazer uma conferência ou uma crítica ao trabalho dos alunos; e esse momento depois chegou em 2008. E foi francamente estimulante 
chegar à Autónoma, voltar a encontrar pessoas que eu muito admirava e estimava, com quem tinha trabalhado, como o José Adrião, por exemplo, ou como o João Luís Carrilho da Graça ou a Inês Lobo, o Francisco e o Manuel Aires Mateus. Foi uma coisa muito estimulante e foi um momento de charneira muito importante, porque o trabalho do atelier antes desse momento é um e, depois disso, é outro.

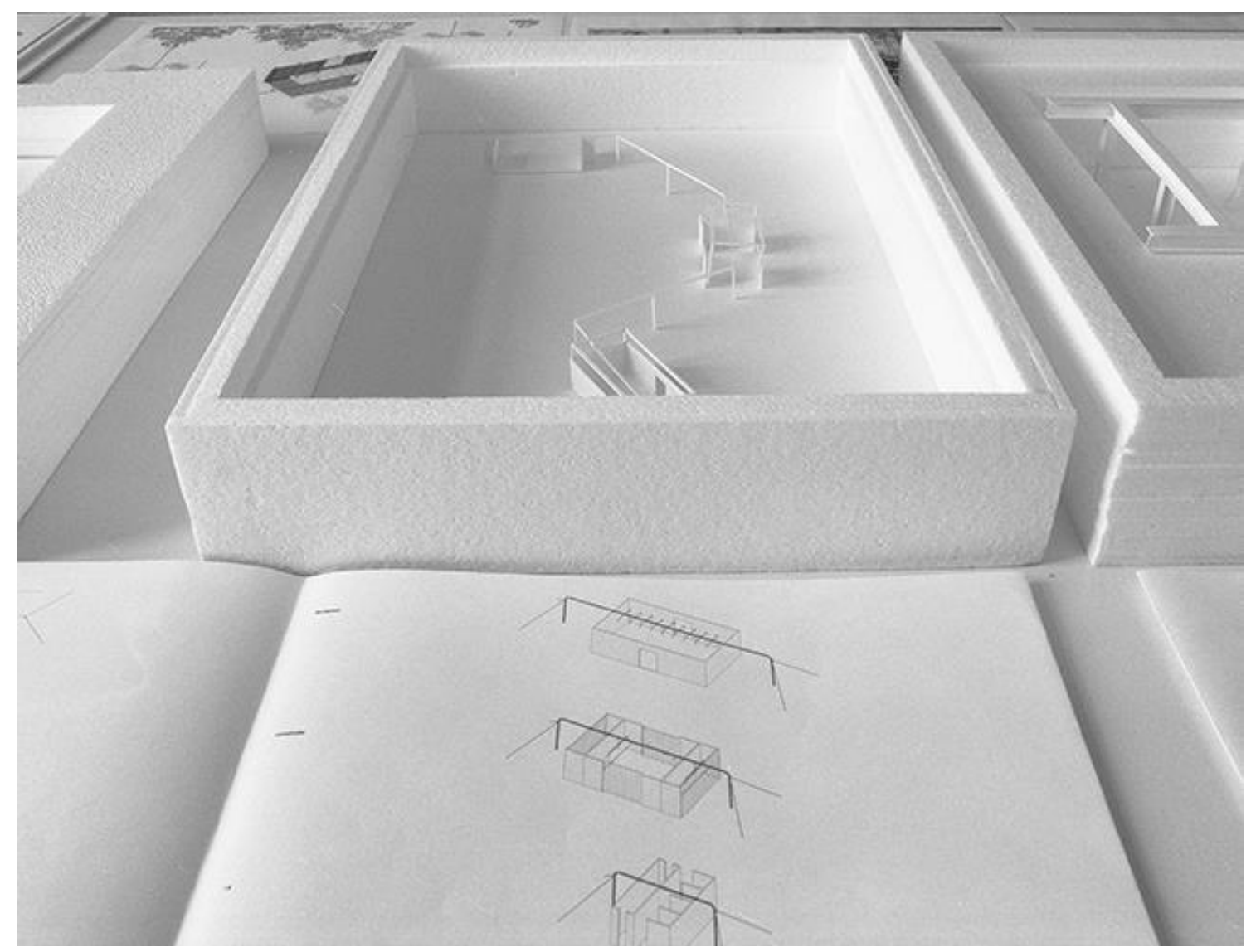

\section{Sentes que houve mesmo uma alteração?}

Sim, houve um início de uma reflexão diferente daquela que eu fazia antes. E é, sobretudo, um impacto bastante grande quando é preciso montar um raciocínio que tenha capacidade de ser transmitido, tenha capacidade de ser objetivamente discutido. Acabamos por perceber que não há qualquer hipótese de haver uma distinção entre uma prática projetual no atelier e uma prática de ensino de projeto na escola. Evidentemente que as ferramentas são outras, mas eu acredito que aquilo que é produzido com os alunos não é muito distante daquilo que pode ser produzido no atelier, evidentemente, com todo o campo de relações preciosas que existem, quer de um lado quer de outro, que são relativamente diferentes; mas sim, senti que era verdadeiramente uma hipótese de fazer aquilo que, de alguma forma, era uma intuição que já tinha no atelier e que, na escola, se tornou muito evidente. 


\section{Isso quer dizer que poderíamos dizer que o Ensino te motivou mais para a Investigação?}

Sim, claro que sim. Quando dizes investigação, eu entendo "investigação" como muitas coisas. A investigação académica está hoje muito vinculada ao preenchimento de etapas com determinação avaliação, pontuação, etc. A investigação do atelier pode ser muito mais aberta e livre. E é essa investigação que conduz a uma coisa que não sabemos bem qual vai ser o fim; e essa investigação pode, enfim, abrir caminhos quase insondáveis de juntar peças que ainda não estavam juntas, de criar desejo de fazer uma investigação sobre arquitetos que são completamente desconhecidos, sobre territórios que não têm ainda inscrição da História da Arquitetura mas que, se calhar, deviam ter. Coisas que são descobertas porque por lá passamos e de repente surgem, e essa manifestação da vontade de investigação, creio, foi aquilo que abriu estas hipóteses que tenho construído nos últimos anos: fazer um trabalho para a Trienal, participar no JA (Jornal Arquitectos), escrever sobre territórios de que gosto e que entendo que são necessários de serem comunicados, os workshops que agora comecei a fazer com o patrocínio da Fundação Millennium-BCP também são isso, são mais uma peça que pode estar no atelier, na escola e nos dois universos, talvez, em simultâneo.

\section{Agora estás no processo do doutoramento. Queres falar sobre a tua investigação? Como é que o tema te surgiu, neste contexto que estás a falar?}

Surgiu neste caminho. O convite do André Tavares e do Diogo Seixas Lopes para fazer o Concurso Universidades para a Trienal foi feito num momento em que eu já estava a pensar em Sines. Era preciso decidir sobre um território e um tema de trabalho para o concurso. O Diogo, o André, a Marta e eu decidimos que Sines e o seu grande conjunto portuário, industrial e urbano, tinham uma potência em estado latente para proporcionar uma experiência de trabalho alargada e diversa a todas as escolas de arquitetura do país. Sines também tinha sido o primeiro tema que eu tinha preparado para a minha primeira aula na UAL, em 2005/2006, quando o Ricardo Carvalho me convidou para fazer uma aula para a sua turma de quinto ano, de História e Teoria da Cidade, creio eu. De repente, a decisão de trabalhar sobre Sines, que tinha sido um primeiro domínio de pensamento para preparar uma aula, voltou a surgir. Fizemos um trabalho super extenso, com todas as escolas de arquitetura do país, eram 900 alunos e foram dois anos de pesquisa, de trabalho sobre aquele território, sobre uma coisa que eu há muito queria fazer: juntar as peças do Gabinete da Área de Sines, que nasce no início dos anos 1970, desaparece no final dos anos 1980, e deixa documentos completamente dispersos sobre uma instalação industrial vastíssima, sobre a criação de uma cidade, a cidade nova de Santo André, feita para os trabalhadores, incrível, cheia de atributos e contributos de arquitetos importantes.

E foi daí que surgiu a vontade em fazer uma investigação sobre esse período e é esse o trabalho de investigação que estou agora a retomar - depois desse primeiro momento de trabalho mais aberto, mais preparatório -, e que vou tentar fechar nos próximos anos. No fundo, sempre tive a ideia de que haveria de ser importante concluir este trabalho de tese, mas pareceu-me que havia de chegar o momento em que isso era mesmo uma coisa que me iria dar gozo e não uma coisa completamente 
irrelevante do ponto de vista da vontade, só para concluir uma tarefa de grau académico. Essa vontade, esse gozo por este trabalho, é muito mais importante.

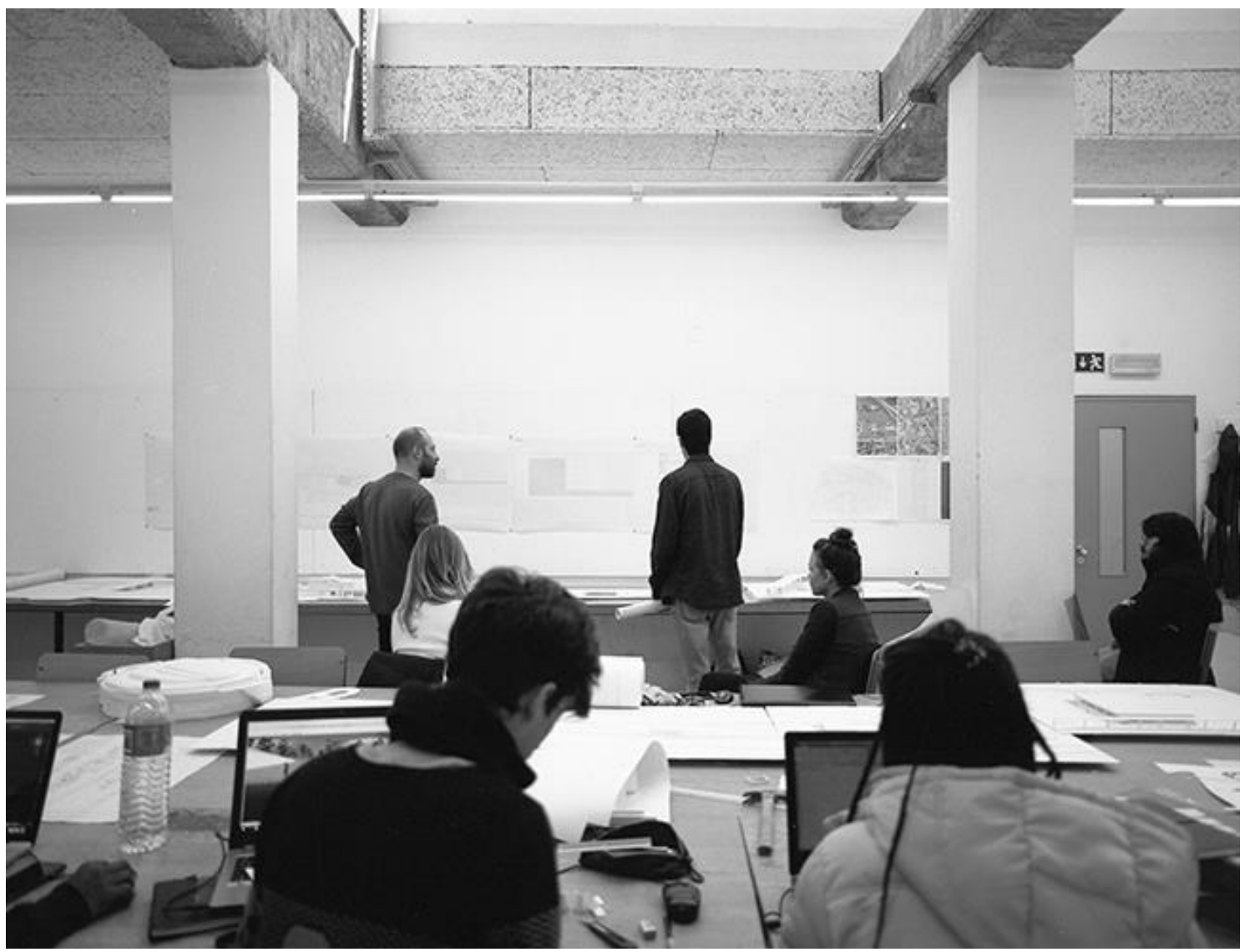

Vou arriscar uma teoria: foste aluno e arrancaste com o atelier em tempos de pré-crise, e, neste momento, vivemos mais ou menos o mesmo tipo de euforia. Há alguma relação que tragas dessa tua experiência para os teus alunos? Ou seja, há alguma relação entre as universidades e o mundo real?

A formação superior, ou formação universitária, é importante para ganhar alguma consistência e algumas referências para que o teu trabalho - qualquer que ele seja depois do teu curso, possa ter muito mais significado e muito mais interesse do que o domínio direto do mercado de trabalho. Uma das coisas que eu gosto bastante de referir aos alunos é que o que vem a seguir, virá - quer dizer, não é direto. Se quisessem fazer um curso cuja relação com o mercado é imediata, direta e rápida, há muitos. Eu acho que o ensino da arquitetura e a aprendizagem da arquitetura estão muito mais relacionados com cursos que, podíamos dizer, são cursos clássicos, em que podes aprender uma cultura, podes confrontar-te com um tipo de cultura clássica. Como a história, a filosofia, a música ou a literatura. E, no fundo, essas são as bases mais fundamentais para reagir, para orientar um percurso profissional a seguir e, 
portanto, eu nem sequer consigo definir se é mais complicado começar agora um atelier ou ter começado nos anos de 1990 ou de 2000. Acho é que talvez o ensino, como eu o conheço hoje, é bastante melhor do que há muitos anos atrás. Há mais escolha, há mais massa crítica, há mais trânsito entre professores e escolas, e há muitos professores, há professores muito diferentes e há métodos de ensino também bastante diferentes.

A determinada altura, também comecei a dar aulas em Évora, em 2012, e o que encontrei são alunos muito diferentes do que os que encontro em Lisboa - e foi muito bonito e estimulante. Em Lisboa temos, na Autónoma, alunos que no fundo são daqui próximo, vêm desde a linha de Cascais, à linha de Sintra, da margem sul... Em Évora, vim a descobrir alunos que vinham de todo o país, vinham muitos do Algarve, de Leiria, de Castelo Branco, do Minho, Trás-os-Montes... E eram realmente pessoas diferentes, ou porque o pai ainda fazia azeite, ou porque outra coisa assim... De repente, aquilo acordava coisas que se calhar estes alunos daqui não conhecem, não sabem o que é. Qualquer método de projeto que se possa inventar, direcionar e consolidar, também tem diferentes interlocutores, aqui são uns, ali são outros.

\section{Mas, agora, na Autónoma, tens muito mais alunos internacionais; este ano, por exemplo, no segundo ano já tens uma turma muito diferente daquilo que eram as turmas até agora.}

Essa talvez seja a grande mudança que a Autónoma tem tido nos últimos anos. Se calhar $50 \%$ dos alunos hoje são estrangeiros. Mas em Évora também, os alunos que eu tenho no quarto ano, vinte são portugueses e vinte são estrangeiros, também vêm de muitos sítios, vêm de Timor, da América Latina... Mas em relação à dificuldade de ter emprego, ter atelier ou produzir trabalho hoje, eu francamente acho que hoje tenho melhores trabalhos no atelier, mas não tenho muito mais do que aqueles que tive nos períodos de crise. Talvez os trabalhos sejam um pouco melhores, porque também vamos aprendendo a gerar o trabalho de uma maneira diferente. Enfim, esta decisão de ser professor, também foi uma escolha para não estar muito refém do mercado de trabalho. Hoje, também tenho essa consciência, de poder, de alguma forma, escolher um pouco os trabalhos que tenho no atelier. Não é que tenha recusado muitos trabalhos, mas também tenho essa consciência de que não quero fazer tudo. Há coisas que me interessam mais do que outras, quer do ponto de vista pedagógico, quer do ponto de vista do trabalho do atelier.

A relação entre o atelier e a escola, para mim, nos últimos quatro ou cinco anos, tomou outras proporções, porque um dia decidi que ia experimentar ter colaboradores que tivessem sido alunos. Até uma determinada altura achei que não era evidente que seria melhor, nem se teria alguma coisa a ganhar com isso. Experimentei, e a verdade é que é ótimo. É ótimo por duas razões: porque parece que metade da conversa já foi feita, parece que já houve uma introdução que não vale a pena reescrever, e porque, efetivamente, os elementos de trabalho e o sistema de trabalho, as peças que eu gosto de construir para trabalhar no atelier, não são diferentes daquelas que gosto de fazer na escola. 
E, evidentemente, nada é muito diferente; os tempos são mais apertados, as etapas são outras, mas não é muito diferente. Hoje tenho no atelier colaboradores quer da Autónoma, quer de Évora, às vezes mais de um lado, às vezes mais de outro. Tudo começou numa altura em que fiz um concurso e, de repente, juntei algumas pessoas das duas escolas, e foi muito bonito para toda a gente, foi muito engraçado e muito útil, acho eu, e a partir daí achei que era mesmo para insistir.

\section{Participaste no JA e também escreves regularmente. Como é que vês o declínio que houve nas publicações sobre arquitetura nos últimos anos? Achas que isso está diretamente relacionado com alguma falta de debate?}

Acho que sim, acho que é muito preocupante. A nossa geração foi habituada a lidar com esse domínio da leitura de grandes revistas que fizeram parte da nossa aprendizagem. A $2 \mathrm{G}$ e a El Croquis, a Casabella, eram revistas que traziam o mundo da arquitetura para todos; e também as nacionais, o JA, sobretudo, foi sempre um jornal onde várias gerações de arquitetos importantes da nossa cultura arquitetónica tiveram os seus momentos de produção e de discussão.

É muito preocupante que não existam hoje, francamente, jornais ou revistas que, organizados por diferentes grupos, por diferentes pessoas da nossa disciplina, possam estabelecer permanentemente discussões sobre o que está a acontecer. O JA, que eu tenha conhecimento, hoje é praticamente um órgão interno da Ordem dos Arquitetos, sem grande direção editorial. A última direção editorial, que aconteceu antes desta fase, com o Diogo Seixas Lopes e com o André Tavares, onde eu participei, estabeleceu uma coisa bastante bonita, com uma radicalidade intrínseca a uma redação de arquitetos fantástica que incluía também os fotógrafos Valter vinagre, Nuno Cera e André Cepeda. A radicalidade da proposta mantinha o respeito do fazer em continuidade com as anteriores direções do Manuel Graça Dias e Ana Vaz Milheiro e, antes, do José Adrião e Ricardo Carvalho, que eram muito claras na sua proposta, eram muito bonitas nesse sentido, queriam obrigar a que a discussão se fizesse daquele modo, com aqueles personagens. Havia revistas que tinham temas, tinham uma palavra, um desígnio para ser investigado, e isso dava ótimas discussões. Recebíamos o JA no atelier e havia sempre um dia que era quase reservado para perceber o que estava ali, o que é que era importante para discutir, se estávamos contra, a favor, se queríamos ir por ali ou não queríamos. Lembro-me de grandes discussões com o Fernando Martins e o Paulo Fonseca (querido amigo arquiteto com quem trabalhei, já falecido).

Eu hoje vejo pouco essa discussão com os nossos alunos. Primeiro, leem pouquíssimo, é uma coisa assustadora. Mas isso, enfim, temos que lá chegar de outra maneira... Mas para nós, enquanto produtores deste universo disciplinar, a híper concentração no domínio do trabalho, sem reflexão, é uma coisa que não nos assiste, não pode ser, não acontece assim, não se faz dessa maneira. Eu acho que há uma perda violenta nesse domínio. E no mundo das publicações generalistas, a arquitetura consegue alguma permeabilidade nesse mundo? Muito pouco, não é? Sabemos que é pouquíssimo, uma coisa residual, é assustador desse ponto de vista. Mesmo com ótimos arquitetos que já o tentaram - com o Manuel Graça Dias à cabeça, que, 
durante muito tempo, tentou essa frente de discussão aberta ao público -, foi muito difícil... O João Luís Carrilho da Graça ou o Gonçalo Byrne, que são pessoas muito intervenientes e que mantêm alguma acutilância em temas públicos, têm pouco espaço, isto tem tudo muito pouca permeabilidade no domínio dos jornais e das revistas generalistas.

E o que é que podemos fazer? É insistir no domínio disciplinar, numa revista para arquitetos, pelo menos essa devia existir. Acho que há pessoas muito interessadas em escrever, há pessoas muito interessadas em divulgar arquitetura, há pessoas muito interessadas em fazer arquitetura nestes modos de maior insistência na cultura disciplinar e não tanto no projeto. $E$ eu acho que isso é uma vantagem. O que aconteceu de verdadeiramente diferente na academia é que hoje os nossos alunos têm a consciência de que podem exercer arquitetura de muitas maneiras, e isso não é um prejuízo para a sua vida como arquitetos.

\section{E em qualquer sítio do mundo.}

Eu acho que a nossa aprendizagem foi outra. Ou eras um arquiteto que tem um atelier e faz arquitetura e que constrói ou vais para a câmara municipal, e isso é o escalão $B$, é para quem não consegue, para quem estava com dificuldade... Hoje os nossos alunos vêm de muitos sítios, sabem muito mais coisas. Depois, verdadeiramente, da disciplina se calhar sabem pouco, mas eu também sabia pouquíssimo, não acho que isso seja um problema para quem é aluno.

Hoje em dia, como arquitetos, estamos expostos a muito mais mundo, e muito mais heterogeneidade construtiva e projetual, do que alguma vez estivemos. Achas que isso se revê no mundo construído?

Eu não consigo ver essa relação tão direta. Primeiro que tudo, acho que nós trabalhamos imenso, construímos muitas ideias para acontecimentos que depois não são construídas como tal, e isso é um prejuízo enorme - para a sociedade em geral, para a nossa vida em coletivo e para o espaço público. Quero dizer com isto que, em todos os ateliers, estão a acontecer trabalhos incríveis, trabalhos super rigorosos e supervaliosos para a sociedade e para todos, mas que depois não são executados, não chegam a ser validados, e hão de permanecer num sítio qualquer, onde alguém um dia os vai descobrir.

Esse é um tema grave, o projeto sai do atelier, chega à obra e é manipulado, e nós temos de estar ali a aguentar a manipulação, faz parte, é um processo - e eu gosto imenso desse processo, gosto imenso de chegar à obra e ter aquele "osso", e de estar ali a sustentá-lo, e a aguentá-lo e a mudar o mínimo; ou mudar o máximo, tanto faz - e às vezes a coisa chega ao fim. Ou, aconteceu-me recentemente, é um desastre. $\mathrm{E}$ como é que esse desastre consegue fazer parte do teu percurso, como é que se passa para outra?... É continuar a tentar, é continuar a construir, é continuar a fazer melhor, a fundamentar melhor, a ter mais clareza no projeto, para que ele tenha menos capacidade de ser resgatado e manipulado. Mas era preciso que isto fosse mais conhecido, porque isto acontece a toda a gente. Em todos os ateliers existem trabalhos que chegaram a isto, desde o arquiteto Siza ao arquiteto mais acabadinho 
de sair da escola. E isso devia ser de alguma forma publicado, discutido, presente numa coisa qualquer, num sítio qualquer onde fosse disponibilizado, para, pelo menos, as pessoas poderem ter esse confronto. No Mercado do Bairro das Estacas, que eu acabei de construir, e, com grande mágoa, ver alterado, as pessoas vêm ter comigo e perguntam: "então, mas não era assim, pois não?".

\section{Ainda por cima, houve uma votação pública, não houve?}

Bom, esse processo então é absolutamente inacreditável! Houve um orçamento público participado, houve uma discussão pública com o orçamento participativo e apresentação de candidaturas, houve uma escolha, uma decisão por votação pública, houve um projeto de execução aprovado pela Câmara Municipal, houve um orçamento aprovado, houve um concurso público de construção, e, de repente, mesmo com tudo isso, chegámos à fase da obra e há atropelos! $E$ as pessoas perguntam: então, mas não era assim? E muitas pessoas não tem essa noção, de que mesmo que o projeto tenha uma autoria, que tenha sido validado, que tenha um orçamento estabelecido, que, ainda assim, tudo pode correr mal porque um qualquer decisor político pode achar que gosta mais ao contrário! E grande parte das pessoas não tem essa noção, acha que não, que, se o projeto é aquele, porque é que não fizeram igual? Só pelas reações que tenho tido ultimamente é que tenho percebido que as pessoas acham que isto é linear: se está validado, se está pago, se está ali o dinheiro para fazer, porque é que não está feito como devia ser?

\section{O João Santa Rita falava-nos no tanto faz, em que há uma altura em que parece que tanto faz...}

É, parece que tanto faz, e isso devia ser mais conhecido, devia ser publicado de alguma forma, se calhar temos de pensar melhor nisto, acho que ainda mais importante do que a revindicação é a comunicação: "olha, é assim que a coisa tem acontecido". Não pode ser uma reivindicação pessoal, tem de ser uma coisa do domínio público, tem de ser uma coisa da discussão do rigor, do que é que se passa, de como é que as disciplinas se cruzam - isso é que eu acho que é verdadeiramente importante. Porque poderíamos todos escrever uns artigos de vez em quando a dizer "ah, trataram-me mal, fizeram-me mal, eu não gosto..." Mas não é essa a questão, nem me apetece escrever um artigo sobre isto, porque não é essa a questão. A questão é o Bairro das Estacas, que devia ser um património classificado e não é, cujo espaço público é danificado, é perturbado por aquela ocorrência, e isso é mais complicado. Preocupas-te em estabelecer argumentos para uma nova construção no seio de um bairro fundamental da cultura arquitetónica portuguesa, a melhor implantação, a geometria e os detalhes, a extensão de uma ideia original de continuidade dos jardins. Foi também por este motivo que lhe chamei Mercado-Jardim: a liberdade de atravessamento junta a grande cobertura com o jardim em contínuo. Pois, gostaram muito do nome, mas não existe jardim: os carros estacionam em cima do mercado. E juntaram umas grades horríveis, para quebrar definitivamente um dos grandes atributos do projeto: a continuidade física e visual do último mercado de levante da cidade de Lisboa. 


\section{estudoprévio}

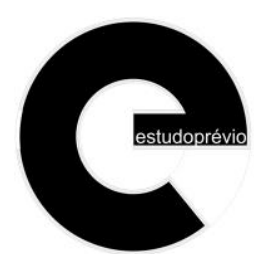

PT | E01 | EP14 | w2018

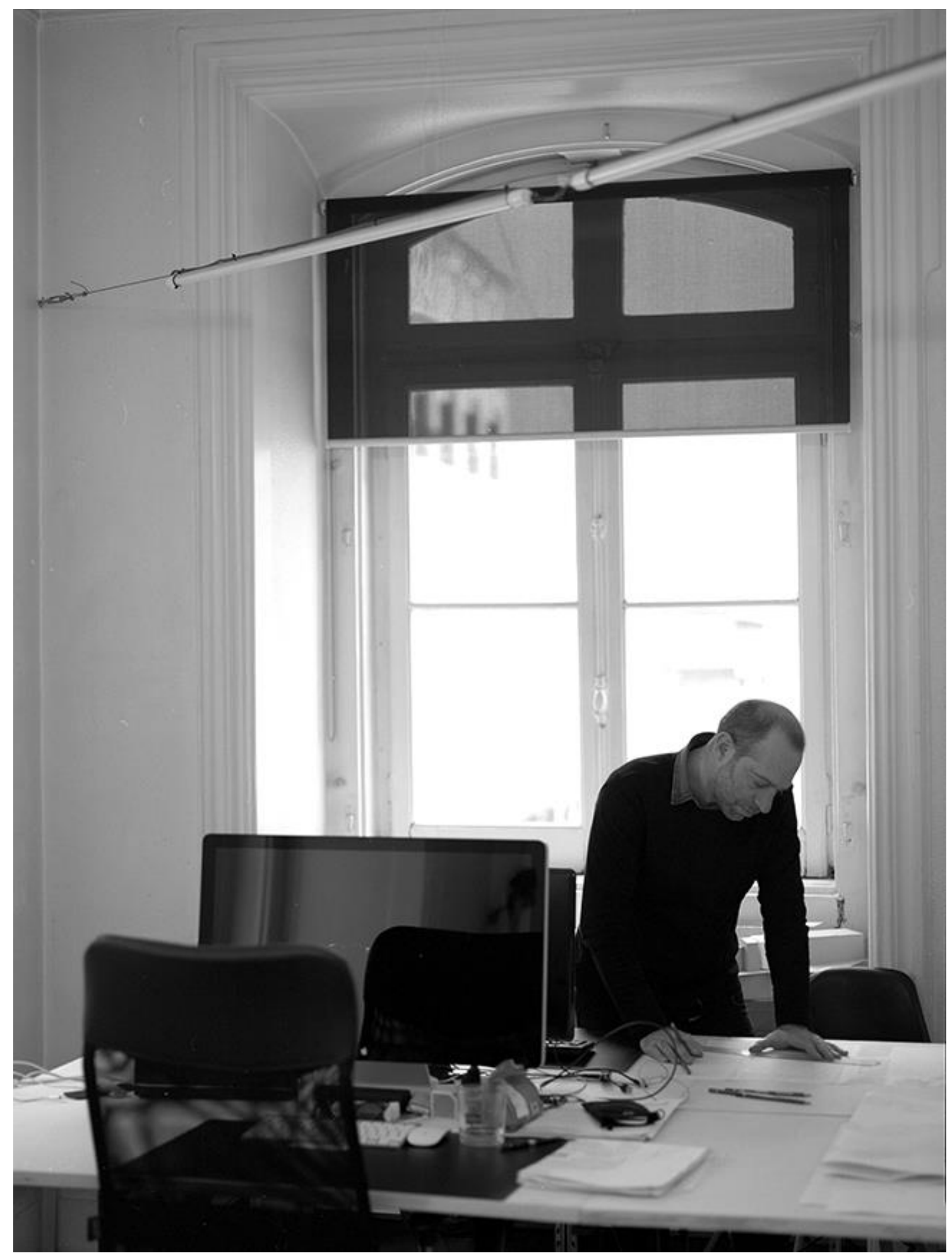


Ainda ontem estava a falar do Martim Moniz, com a Inês Lobo, e estava a falar sobre a demissão das pessoas da discussão do que devia ser a cidade, em primeiro lugar dos arquitetos, mas não é só dos arquitetos, porque toda a gente o faz... Estávamos a falar das coisas que têm sido feitas em Lisboa e daquela impressão que fica nas pessoas de que, apesar de tudo, as coisas estão melhores, os espaços melhoraram. Mas continuamos sem essa discussão. E eu não sei como é que se muda isto.

Sem dúvida. Eu tenho a ideia de que o in situ/, que fazem aqui no CEACT/UAL, é ótimo. É menos permeável, porque é muito académico. Quando inventei estes novos laboratórios de arquitetura (com o Paulo David e o João Gomes da Silva, no Funchal, e agora fiz outro em Beja com o Manuel Faião e o Ricardo Bak Gordon e a Ana Vaz Milheiro), uma das coisas que discutimos bastante era como é que um exercício feito por arquitetos, para um determinado sítio, pode ser visto e observado pelas outras pessoas que também pensam sobre o domínio público: os historiadores, os engenheiros, os geógrafos, e por aí fora. $E$ uma das coisas que foi muito bonito no Funchal, quando fizemos o primeiro laboratório, foi termos tido a visita de várias pessoas. Todos os dias havia uma conferência, todos os dias havia uma aula aberta para a cidade. $\mathrm{E}$ todas as pessoas que convidámos para lá estar acabaram por trazer pessoas da sociedade, atentas e curiosas com o que ali se passava, e a maior parte delas desconhecia absolutamente como é que os arquitetos trabalhavam, como trabalham. Não faziam ideia nenhuma de como acontece um exercício de arquitetura sobre um lugar, sobre um edifício. E essa é uma estupefação, por um lado, claro, mas é uma coisa que temos de ter a capacidade de mudar. Neste último, em Beja, o trabalho era sobre o Bairro dos Alemães - que estou agora a tratar, para construir um pequeno livro sobre aquele território, para o inscrever também na História da Arquitetura Portuguesa. E o início desse processo foi juntar peças, colocar a Câmara Municipal a trazer do seu arquivo os documentos que existem, a Força Aérea a mesma coisa. Os alunos foram visitar estes sítios, e começaram a organizar os processos com todas as peças que pudessem incluir um processo de projeto, tivemos também as aulas abertas, tivemos a visita de pessoas que foram ver as aulas, para saber como é que aquele trabalho se podia produzir. Porque a ideia que há é que existe um autor, existem uns desenhos, uns alçados, e a Câmara Municipal depois é que diz como é que é. Ainda há um desconhecimento grande sobre como é que se produz um projeto, e estes laboratórios têm tentado comunicar um pouco isso. $\mathrm{E}$ produzir documentos que possam ficar.

O nosso desafio (como organização do in situ/) é sempre a construção. Terem de se confrontar com a passagem do projeto à realidade quando há limitações, que neste caso são de tempo, de material, da própria mão de obra, da força que eles têm para fazer as coisas...

Estava a ouvir e acho que me falta falar aqui de uma ou duas pessoas que têm sido muito importantes para mim, nestes últimos anos de trabalho, que são a Fernanda Fragateiro e a Marta Labastida. Com a Fernanda Fragateiro vejo a construção do lado dos artistas: passa do projeto para a execução, é realmente outra liberdade, que eu invejo absolutamente. De facto, não é liberdade absoluta, claro, como sabemos, mas 
não há os constrangimentos que nós temos - com o programa, com o cliente, com a tipologia, com a organização, com os fundamentos daquilo que estamos a fazer, que são atributos que a arquitetura tem, e que são, talvez, inigualáveis. A quantidade de coisas que se juntam para fundamentar uma coisa, as pessoas que a constroem, é muito difícil encontrar outra disciplina que tenha uma complexidade tão grande. O que me faz concluir que é um milagre quando se vê qualquer coisa bem desenhada, com uma ideia absolutamente clara, com relações bem definidas e bem decididas! É quase um milagre, achamos que é tudo possível, mas é mesmo difícil acontecer! Com a Fernanda, só para concluir, aprendi isso sobretudo, e aprendi que, nas maiores dificuldades, tudo pode ser feito com respeito e elegância, e manter o combate!

Referi também a Marta Labastida, que conheci a propósito do JA, onde trabalhámos juntos, e depois também no trabalho da Trienal, onde o André e Diogo nos juntaram naquela curadoria. Sendo uma pessoa que tem trabalhado muito sobre domínios que me interessam muito, como o espaço público, trabalhou com o Solá-Morales, e vem desse registo da discussão do que é publico. Com a Marta estou a trabalhar noutras coisas, em como o desenho pode ser mais matéria do que pensamento, e até, muitas vezes, pode ser mais rápido a chegar ao contexto da construção e a ficar menos retido no domínio da conceção.

Tu és muito rigoroso na expressão da escrita e oral, o que tem a ver com o rigor do pensamento. É algo em que penso muito, perante a internacionalização, porque a língua define o nosso pensamento, a forma como expressamos aquilo que queremos. Parece-me uma escolha consciente, esse rigor. E queria saber se isso é propositado, se é uma coisa que tu construíste.

Acho que é muito importante e estimulante, mesmo na relação com os alunos, no processo pedagógico e didático, referir que decidir como é que se diz isto ou aquilo é um modo como podemos transmitir melhor ou pior quer o que estamos a pensar, quer o que estamos a construir. Agora tenho construído dois exercícios, que gosto cada vez mais de fazer. Isto começou quando, há cinco anos, comecei a dar aulas com o João Santa Rita na Autónoma. Habitualmente, estou com o Ricardo Carvalho no primeiro semestre e com o João Santa Rita no segundo; em Évora, com o Pedro Pacheco. (Também já partilhei docência com o Daniel Jimenez, com o João Soares e com o João Matos, o José Adrião, a Sofia Salema.) São pessoas diferentes, e usamos métodos diferentes, mas havia qualquer coisa que podia ser comum - era construir, quando um exercício se produz, um elemento gráfico e um elemento escrito. E esse elemento escrito tem de dizer, de traduzir, exatamente, em palavras, o que está desenhado, como se fosse uma transcrição literal. E isso é um exercício difícil, é um exercício de atenção e de ensaio. É preciso ensaiar.

E a outra coisa que eu acho que também é importante, tenho pensado nisso como cada vez mais importante, é organizar o método que usamos para fazer projeto. Definem-se fases absolutamente instrumentais, ou seja, tem de fazer aquele documento, àquela escala, com aquele lápis, com aquela base, e não pode ser diferente, tem de ser aquele, tem de ser desta maneira. E para quê? Para nada, é um instrumento! Mais tarde, logo se vê para que serve, não tem um valor imediato como 
construção; e isso tem gerado coisas interessantes - é aquilo que é para fazer, tem mesmo de ser bem feito. Aquela peça ficou bem feita, depois têm dez peças bem feitas, e isso é o projeto, já está! E constrói-se a narrativa com isso.

\section{No mundo em revolução em que vivemos, tecnológica pelo menos, quais é que são as ferramentas que tu eleges como essenciais para a continuação da arquitetura como disciplina?}

Hoje de manhã vinha a ler o jornal, e estava a ler um pequenino texto sobre o concerto performance que a Laurie Anderson fez a semana passada em Lisboa. O que se dizia nessa peça era que houve uma altura em que todos os seus objetos, todo o seu pequeno mundo, as peças que ela tinha de todo o seu trabalho, estavam numa cave; e, de repente, houve uma inundação em Nova lorque e ela ficou sem nada. E teve de montar outro raciocínio, para pensar no mundo sem as suas coisas. E chegou à conclusão de que a memória das coisas e a palavra que regista a memória das coisas, esse resíduo que é a palavra e a frase, o texto sobre as coisas que constroem a sua memória, é muito mais importante do que as coisas em si, do que as peças propriamente ditas. $E$ isso é que pode ser transmitido, e isso é que pode ser eventualmente continuado por alguém. É inquietante.

Eu confesso que o mundo material me seduz muito mais do que o mundo imaterial, sou colecionador de coisinhas, e as coisinhas fazem-me falta! Quando escrevo tenho de ter vinte livros à volta, quando projeto tenho de ter as fotografias dos edifícios de que eu gosto, isso faz-me muita falta para montar alguma coisa. Eu sinto que, quando está a ser dito que o mundo agora é assim, ou que agora a dificuldade é esta, é porque já está a acontecer outra coisa qualquer. Isso já foi, no fundo o que conseguimos dizer já foi triturado pelo serviço político de esmagamento do pensamento. E nessa situação temos de deixar palavras para trás: não as usar, a partir do momento que entram nos discursos políticos.

Um certo ano fiz com amigos uma proposta para o orçamento participativo: usar alguns logradouros da cidade para um uso público preciso. A proposta apareceu a votação com "o uso dos espaços de logradouro para estacionamentos, hortas, parques de recreio infantis", tudo em pacote, como indiferenciados da mesma ideia. Esta é a maior tragédia da cultura política portuguesa. Regra geral, não distinguem uma obra-prima de uma obra banal. E, portanto, tudo está sempre mais próximo da calamidade. Na verdade, sinto que todos os dias acontecem.

Outra coisa que li recentemente, que muito me seduz e que gosto de reproduzir de vez em quando, a senhora, D. Antónia, que é a fundadora do Vinho do Porto Ferreirinha, que dizia há pouco tempo numa entrevista: "Pois, mas isso é difícil, fazer um vinho é uma coisa complexa, há muitas variáveis. Isto realmente é difícil, mas o que custa mesmo são os primeiros 250 anos, isso é que é mesmo difícil. Passando isso, a coisa já vai quase bem."!

É determinante pensar num tempo que não é finito, para as tuas ações. Julgo que este é um sentido importante para a noção de política e do que é publico. 


\section{estudoprévio}

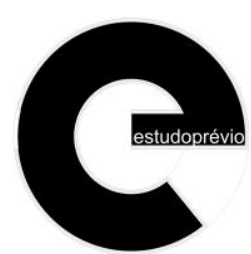

PT | E01 | EP14 | w2018

Portanto, os instrumentos que eu acho que vão sobrar? Não sei. Mas de certeza que a palavra e o discurso vão ter imensa importância. 